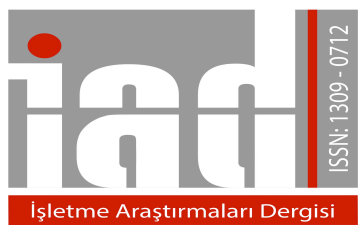

Journal Of

Business Research

Turk

www.isarder.org

\title{
Kurumsal Sosyal Sorumluluk Kapsamında Çevre Açıklamaları İle Firma Özellikleri Arasındaki İlişki: Kimya, Petrol, Kauçuk ve Plastik Ürünler Sektöründe Bir Uygulama
}

\section{Relation Between Company Features And Environmental Statement Within Corporate Social Responsibility: An Application In Chemistry, Petroleum, Rubber And Plastics Products Industry}

\author{
Şule YILDIZ \\ Sakarya Üniversitesi \\ İşletme Fakültesi \\ İşletme Bölümü, \\ Sakarya, Türkiye \\ kasapoglu@sakarya.edu.tr
}

\author{
Gülfen TUNA \\ Sakarya Üniversitesi \\ Siyasal Bilgiler Fakültesi \\ Finansal Ekonometri \\ Bölümü, Sakarya, Türkiye \\ geksi@sakarya.edu.tr
}

Vedat Ender TUNA

Sakarya Üniversitesi

Sosyal Bilimler Enstitüsü

Sakarya, Türkiye

vedattuna@hotmail.com

\section{Özet}

$\mathrm{Bu}$ araştırmanın amacı, firmaların yıllık faaliyet raporlarında yer alan çevresel açıklama miktarları ile firma özellikleri arasındaki ilişkinin tespitidir. Bu amaçla Borsa İstanbul da işlem gören, kimya, petrol, kauçuk ve plastik ürünler sektöründe faaliyet gösteren 19 adet firmaya ait faaliyet raporları; 2008-2014 dönemi için içerik analizi yöntemiyle incelenmiştir. Araştırma kapsamında incelenen firma özellikleri; büyüklük, özsermaye karlılığı, aktif karlılığı, borçlanma düzeyi, borsaya kote olma tarihi ve firmanın kuruluş tarihidir. Araştırmada çevresel açıklama düzeyi ile bağımlı firma özellikleri arasındaki ilişki panel regresyon metodu ile analiz edilmiştir. Araştırma sonuçlarına göre; çevresel açıklama düzeyi, firmanın kuruluş tarihi ve borçlanma düzeyi ile pozitif; büyüklük ve borsaya kote olma tarihi ile negatif ilişkili olup, istatistiksel olarak anlamlıdır. Ancak özsermaye karlılığı ve varlık karlılığı ile çevresel açıklama düzeyi arasında istatistiksel olarak anlamlı bir ilişki bulunamamıştır.

Anahtar Kelimeler: Çevresel Açıklama, Firma Özellikleri, Firma Performansı, Faaliyet Raporu

\begin{abstract}
The purpose of this research is to determine the relation between company features and environmental statement amounts in the annual activity reports of companies. To this end, activity reports of 19 companies making business in chemistry, petroleum, rubber and plastic products industry in Borsa Istanbul were inspected with content analysis method for 2008 - 2014. The company features inspected within the research are size, equity profitability, active profitability, debt levels, stock market listing date and date of foundation of companies. In the research, the relation between environmental statement level and related company features were analyzed with panel
\end{abstract}


regression model. According to the results of research, the environmental statement level has positive relation with date of foundation and debt level and it has negative relation with size and stock market listing and it is statistically meaningful. However, no statistically meaningful relation was found between equity profitability and asset profitability and the environmental statement level.

Keywords: Environmental Disclosure, Company Charachteristics, Firm Performance, Annual Report

\section{GİRIŞ}

Küreselleşme olgusu işletmelere hızlı büyüme, yüksek kar elde etme gibi finansal hedeflerin yanısıra; dünyada yaşanan çevresel sorunlara daha duyarlı olma konusunda yeni sorumluluklar getirmekte ve bu doğrultuda gerçekleştirilen düzenlemelerde çevresel sorumluluk düzeylerinin artmasına neden olmaktadır. Kurumsal sosyal sorumluluk ve sürdürülebilirlik kapsamında değerlendirilen çevresel sorumluluklar, bir işletmenin ekonomik faaliyetlerinin ekosistemler üzerindeki etkisi ile ilgilidir. İşletmeler çevreye yönelik olumsuz etkilerin azaltılması ve çevresel performansın artırılması konusunda müşteriler, hissedarlar, yatırımcılar, kreditörler, sivil toplum örgütleri, ulusal ve uluslararası kuruluşlar gibi pek çok farklı grubun baskısı altındadır.

Toplumsal baskılara yanıt olarak ve küresel rekabet ortamında sürdürülebilir, güvenilir, şeffaf ve hesap verebilir bir şirket imajı oluşturabilmek için; günümüzde işletmeler yasal zorunluluk olmasa bile gönüllü olarak çevresel konulara dikkat etmekte ve çevreye olan duyarlılığın bir göstergesi olarak çevresel açıklamalara yer vermektedir. Bu doğrultuda geri dönüşümlü malzeme kullanımı, yenilenebilir enerji üretimi, emisyon salınımının azaltılması, etkin atık yönetimi, ağaçlandırma faaliyetleri vb. uygulamalara ilişkin bilgiler çevresel performans göstergesi olarak ilgili raporlarda yer almaktadır.

İşletmelerin üstlendiği yeni sorumluluklara ilişkin paydaş beklentilerini karşıladığına dair bilgiler; faaliyet raporu, kurumsal yönetim ilkeleri uyum raporu, çevre raporu, sürdürülebilirlik raporu, kurumsal sosyal sorumluluk raporu, sosyal sorumluluk raporu gibi farklı isimlerle oluşturulan raporlar ile düzenli olarak açıklanmaktadır. Sözkonusu raporlar içinde genellikle yıllık faaliyet raporları ya da çevresel raporlar, çevresel açıklamalar için önemli bir araç olarak kullanılmaktadır. Bu raporlarda yer alan çevresel açıklamalar; şirketlerin kurumsal sosyal sorumluluk kapsamında genel çevre politikaları, çevre yönetim ve çevresel etki değerlendirme sistemleri, çevresel maliyet, çevresel yatırım gibi işletme faaliyetlerinin çevresel etkileri hakkında bilgi vermektedir.

Başka bir ifadeyle, kurumsal çevresel açıklamalar, firmanın geçmişteki, bugünkü ve gelecekteki çevresel yönetim kararları ve ekonomik faaliyetlerinin mali etkileri; çevresel faaliyetleri ve performansıyla ilgili bilgilerin bütünüdür (Berthelot, Cormier, ve Magnan, 2003, s. 2). Bu tarz gönüllü çevresel açıklamalar, şirketlerin uzun vadede finansal performansını, piyasa ve marka değerini, kurumsal imaj ve itibarını artırmada etkili olabilmektedir. Çünkü bugün, işletmeler sadece bilançoları, karları gibi mali sermayeleri ile değil aynı zamanda sosyal sorumluluk faaliyetleri ile de değerlendirilmektedir. Örneğin, işletmenin çevreye olan duyarsızlığı onu bir anda negatif anlamda medyanın hedefi haline getirebilmekte, işletme kamu kesiminden kredi almakta sorunla karşılaşabilmekte, hisse senetlerinin borsadaki değeri düşebilmekte, ayrıca kalifiye iş gücü için tercih edilir bir işyeri olmaktan çıkabilmektedir (Ateşoğlu ve Türker, 2010, s. 210). 
Kurumsal sürdürülebilirliği esas alan yeni paradigmaya göre, bir işletmenin genel performansının belirleyicileri yalnızca finansal sonuçlar değil, sosyal ve çevresel performans bütünüdür. $\mathrm{Bu}$ yaklaşım işletme faaliyetleriyle etkileşim halindeki tüm taraflara finansal bilgilerin yanında çevresel ve sosyal bilgilerinde raporlanmasını gerektirir (Önce, Onay ve Yeşilçelebi, 2015, s. 235). Deegan (2002) çevresel bilgi raporlama konusunda yöneticileri motive eden unsurlar1; sorumluluk bilincine sahip olma, borçlanma şartlarına uyma, toplumsal beklentileri karşılama, paydaşların menfaatlerini yönetmek, işletmeye yatırım fonu çekme, raporlamaya ilişkin ödüller kazanma ve daha kapsamlı raporlamaya ilişkin yasal düzenlemelerin önüne geçme olarak ifade etmiştir (Burgwal ve Vieira, 2014, s. 62).

Çevresel açıklamaların stratejik bir araç olarak şirketlerin yıllık raporlarında yer alması paydaş teorisi ve meşruiyet teorisi tarafından da desteklenmektedir. Meşruluk teorisine göre gönüllü çevresel açıklamalar, şirketlerin içinde bulundukları toplumun doğal çevreye karşı tutumuna ilişkin beklenti, kural, değer ve inançlarına uyduklarını göstererek meşruluk kazanmak ve korunmak için kullanabilecekleri önemli bir araçtır. Benzer şekilde, şirketin başarısını tüm paydaşlarla olan ilişkilerin etkin yönetilmesine dayandıran paydaş teorisi de gönüllü çevresel açıklamaların paydaşların algılarını olumlu yönde yönetmek üzere bir strateji olarak kullanılabileceğini söylemektedir (Almagtome, 2015, ss. 47-50). Böylece bu iki teori doğrultusunda çevresel performans hakkında bilgi paylaşımı yapan şirket, uzun vadede olumlu tüketici ve yatırımcı davranışı olarak geri dönüş alabilmektedir.

Kurumsal sosyal sorumluluk ile birlikte hissedar ve diğer paydaş gruplarının artan bilgi talebi nedeniyle işletmelerde çevre muhasebesi, çevresel yönetim muhasebesi, çevresel maliyet, çevresel açıklama ve çevresel raporlamanın önemi giderek artmış ve bu çerçevede çok sayıda araştırma yapılmıştır. Türkiye özelinde ise kurumsal çevresel açıklamaların firma karakteristikleri bağlamında belirleyicileri konusuna doğrudan değinen tek ampirik çalışma Akbaş (2014) tarafından gerçekleştirilmiştir. Akbaş çalışmasında tek bir yıl (2011) verilerini kullanarak bazı firma özellikleri ile çevresel açıklamalar arasındaki ilişkiyi araştırmıştır. Bu çalışma ele alınan dönem, örneklem ve kullanılan değişkenler açısından Akbaş (2014)'ın çalışmasından farklılaşmaktadır. Bu araştırmanın mevcut literatürdeki çalışmadan en önemli farklılığ 1 panel verinin kullanılmasıdır. Böylece sektörde yer alan birden fazla firmanın, birden fazla yıl için çevresel açıklama düzeyi ile firma özellikleri arasındaki ilişki incelenebilmiştir. Ayrıca literatürdeki mevcut çalışmaların hiçbirinde firmanın borsaya kote olduğu tarihin, çevresel açıklama düzeyi üzerindeki etkisini inceleyen çalışmaya rastlanılmamıştır. Firmaların borsada işlem görmeye başlaması, daha şeffaf bir yatırım ve yönetim ortamının da oluşması noktasında önemlidir. Kamuyu aydınlatma ilkesi gereğince, firmanın sosyal sorumlulukları hakkındaki hassasiyetinin ve bilgilendirilmesinin de en üst düzeyde olması beklenmektedir. Bu nedenle firmaların borsaya kote olma tarihleri ile çevre bilinçleri arasında herhangi bir anlamlı ilişkinin olup olmadığının tespiti noktasında bu çalışma ayrıca önemlidir.

Çalışma sonucunda firmalar arasında çevresel açıklamalarda görülen farklılaşmanın nedenlerinin anlaşılmasının; gerek işletme yönetimini gönüllü çevresel açıklama miktarını artırarak çevresel raporlama yapma, gerekse kanun koyucuları mali tablolarda çevresel bilgilere yer verilmesinin zorunlu tutulması konusunda teşvik edici olacağı; ayrıca yatırımcılar ve diğer paydaş grupları için fayda sağlayacağı düşünülmektedir. Yine çevresel açıklamaların artan önemi nedeniyle çevresel 
raporlama/sürdürülebilirlik raporlaması konularında yapılan araştırmalara katk1 sağlayacağı beklenmektedir.

$\mathrm{Bu}$ doğrultuda çalışmanın amacı şirket kurumsal çevre açıklamaları ile firmanın büyüklüğü, özsermaye karlılığı, aktif karlılığı, borçlanma düzeyi, borsaya kote olma tarihi ve firmanın kuruluş tarihi olarak belirlenen şirket özellikleri arasındaki ilişsiyi incelemektir. $\mathrm{Bu}$ amaç doğrultusunda çalışma dört bölümden oluşmaktadır. Giriş bölümünün ardından ikinci bölümde konuya ilişkin literatür taramasına yer verilmiş, üçüncü bölümde ise çalışmada kullanılan veri seti ve model açıklanmıştır. Dördüncü bölümde yapılan analiz sonucunda elde edilen ampirik bulgulara ilişsin bilgiler yer almaktadır. Son bölümde ise elde edilen bulgulardan yola çıkılarak genel bir değerlendirme yapılmıştır.

\section{LITERATÜR TARAMASI}

Kurumsal sosyal sorumluluğa dair çok sayıda araştırma yapılmış olmasına karşılık çevresel raporlama-çevresel açıklama özelinde yapılmış çalışma sayısı görece olarak daha azdır. Aşağıda uluslararası ve ulusal literatürde şirketlerin çevre açıklamalarını konu alan çalışmalara yer verilecektir.

Harte ve Owen (1991) tarafindan, İngiltere deki 30 şirketin yıllık faaliyet raporlarındaki çevresel açıklamaların incelendiği çalışmada; raporlardaki çevresel bilgi seviyesinin nispeten düşük olduğu ve daha çok çevresel konulara genel bir bağlılık olarak değerlendirilebileceği sonucuna ulaşılmıştır.

Bewley ve Li (2000), çalışmalarında, gönüllü açıklama teorisi çerçevesinde 188 Kanadalı üretim firmasının 1993 yılı faaliyet raporlarındaki genel ve finansal çevresel bilgi açıklamalarını Wiseman İndeksini kullanarak ölçmüşlerdir. Çalışma sonucunda, yüksek düzeyde kirliğe sebep olma, çevreye zarar verme eğilimi ve siyasi etkileri konusunda medyada sık yer alan şirketlerin genel çevresel bilgi açıklamalarına daha yatkın olduğu sonucuna ulaşılmıştır.

Gray ve Diğ., (2001) tarafından İngiltere'deki şirketlerin 1988-1995 dönemi yıllık raporlarındaki çevresel açıklama miktarı ile firma özellikleri arasındaki etkileşimin incelendiği çalışma sonucunda, büyüklük, karlılık ve içinde bulunulan sektör ile çevresel açıklama düzeyi arasında pozitif bir ilişki tespit edilmiştir.

Hughes, Anderson, ve Golden (2001), çevresel açıklamaların gerçek çevresel performans göstergesi olarak kullanılıp kullanılmayacağını araştırdıkları çalışmada, 51 ABD üretim firmasının 1992 ve 1993 dönemi çevresel açıklamalarını esas almışlardır. Araştırma sonucunda farklı çevresel performans puanlarına sahip şirketlerin çevresel açıklamaları farklılaşmasına rağmen bu ayrımın firmanın gerçek performans düzeyini sınıflandırma için yeterli olmadığı sonucuna ulaşılmıştır. Ayrıca düşük seviyede puan alan çevresel performans gruplarının, diğer gruplara nazaran daha fazla açıklama yaptıkları gözlenmiştir.

Patten (2002), çevresel açıklama ile çevresel performans arasındaki ilişkiyi araştırdığı çalışmada, 24 farklı sektörde faaliyet gösteren 131 ABD şirketinin 1990 yılı faaliyet raporlarını wiseman indeksi ve içerik analizi yöntemi ile incelemiştir. Yazar satışla normalleşmiş Toksik Madde Salınım Envanteri (TRI) verilerini kullandığ çalışmada, TRI/satışlar ve çevresel açıklama ölçütleri arasında olumlu bir ilişki 
belirlerken, çevresel performans ve çevresel açıklamalar arasında ise olumsuz bir ilişki olduğunu tespit etmiştir.

Campbell (2004), çalışmasında beş sektörden 10 adet şirketin 1974-2000 dönemi yıllık raporlarını gönüllü çevresel açıklama miktarı açısından incelemiş ve 1980'lerin sonundan itibaren açıklama hacminde belirgin bir artış olduğunu tespit etmiştir. Benzer şekilde Cowan ve Gadenne (2005), Avusturalyalı şirketlerin 1998-2000 dönemi için yıllık raporlarındaki gönüllü ve zorunlu çevresel açıklamaları içerik analizi yöntemiyle incelemiştir. Araştırma sonucunda ilgili şirketlerin raporlarda gönüllü çevresel açıklamalara yasal zorunluluk gereği yapılan açıklamalardan daha fazla yer verdikleri görülmüştür.

Al-Tuwaijri, Christensen, ve Hughes (2004), eş zamanlı denklemler modeli ile 198 firma verilerini kullanarak ekonomik performans, çevresel performans ve çevresel açıklama arasındaki ilişkileri araştırmışlardır. Patten'ın çalışmasına benzer şekilde yazarlar da çevresel performans ölçümünde TRI (toksik madde salınım envanteri) temelli veriler kullanmışlar ve geri kazanılan toplam atık yüzdesini çevresel performans kriteri olarak değerlendirmişlerdir. Araştırma sonucunda çevresel performans, çevresel açıklama ve ekonomik performans arasında olumlu bir etkileşim olduğu tespit edilmiştir.

Clarkson ve Diğ., (2008), ABD de faaliyet gösteren 191 firma üzerinde yaptıkları çalışmada, çevresel performans ile gönüllü çevresel açıklamalar arasındaki ilişkiyi araştırmışlardır. Araştırma sonucunda çevresel-sosyal raporlarda ve ilgili web sayfalarında yapılan gönüllü çevresel açıklama düzeyi ile çevresel performans arasında olumlu bir ilişki olduğunu tespit etmişlerdir.

Pahuja (2009), Hindistan'daki büyük ölçekli üretim firmaları üzerinde yaptığı çalışmada, şirketlerin çevresel açıklamaları ile firma özellikleri arasındaki ilişkiyi araştırmıştır. Bu amaçla, çevresel açıklama indeksi oluşturulmuş ve üç yıllık bir süreçte şirketlerin faaliyet raporları incelenerek çevresel açıklama puanları belirlenmiştir. Yapılan çoklu regresyon analizi sonucunda, şirketlerin büyüklük, içinde yer aldıkları sektör, karlılık gibi özellikleri ile çevresel performansları arasında önemli bir etkileşim olduğu tespit edilmiştir.

Liu ve Anbumozhi (2009), paydaş teorisi perspektifiyle Çin de borsaya kayıtlı şirket verilerinden hareketle firmaların kurumsal çevresel bilgilendirme düzeyini belirleyen faktörleri araştırmışlardır. Araştırma sonucunda, örneklemi oluşturan firmaların \%40'ının önemli çevresel faaliyetler hakkında toplumu bilgilendirmediği, şirketlerin çevresel bilgi stratejilerini etkilemede hissedar, kreditörler gibi paydaşların rolünün zayıf olduğu, mevcut uygulamaların hükümetin çevre konusundaki kaygılarını gidermeye yönelik olduğu tespit edilmiştir. Yine şirketlerin ekonomik performans1 arttıkça çevresel yatırım, emisyon ve çevre kirliliği kontrol maliyetlerine ilişkin daha fazla açıklama yaptıkları ve çevre bilgilendirme çabalarının büyük oranda çevre duyarlılığ1 ve şirketin büyüklüğü ile ilgili olduğu tespit edilmiştir.

Wu, Liu ve Sulkowski (2010) tarafindan firma özellikleri, firma performansı ve çevresel açıklamalar arasındaki ilişkiyi tespit için S\&P 100 endeksindeki 287 firma üzerinde yapılan çalışmada 2004-2008 yılları arasında belirlenen anahtar kelimelerin sıklığı sayımı ile firma raporlarındaki çevresel açıklama miktarı ölçülmüştür. Sonuçlar, firma büyüklüğü, yaş ve kaldıraç oranı ile çevresel açıklama miktarı arasında negatif 
yönlü bir ilişki olduğunu göstermiştir. Yine yüksek kaldıraç oranına sahip ve finansal performansı iyi olan firmalar daha az çevresel açıklama yapma eğilimindedirler.

Huang ve Kung (2010), kurumsal çevresel açıklama ile paydaş beklentileri arasındaki ilişkiyi inceledikleri çalışmada Tayvan borsasına kayıtlı 759 şirketin 20032005 dönemi yıllık faaliyet raporlarındaki çevresel açıklamaları esas almışlardır. Çalışma sonuçları hükümet, kreditörler, tüketiciler gibi dış baskı grupları yanında hissedar ve çalışanlardan oluşan iç paydaş gruplarının beklentilerinin çevresel açıklama düzeyi üzerinde önemli etkisi olduğunu göstermiştir. Yine çevre koruma organizasyonları ve muhasebe kurulları da çevresel açıklama stratejinin tespitinde şirketin yönetsel seçimlerini etkilemektedir.

Zeng, Xu, Dong ve Tam (2010),tarafından Çin'de borsada işlem gören 871 üretim firmasının verileri kullanılarak yapılan çalışmada firmaların kurumsal çevresel bilgi açıklama düzeyi incelenmiştir. Sonuçlar, petrol, gaz sektörleri gibi çevreyi kirletme potansiyeli yüksek olan şirketlerin hükümet baskısının da etkisiyle çevresel bilgi açıklama düzeyinin de yüksek olduğunu ve örgütsel imaj ve itibar gibi değişkenlerin firmaların çevresel açıklama içeriğini etkilediğini göstermiştir.

Cho, Roberts ve Patten (2010) kurumsal çevresel açıklamalarda kullanılan dil ve üslubun şirketin çevresel performansına göre nasıl bir değişiklik gösterdiğini inceledikleri çalışmada, 190 firmanın 2002 yılı raporlarındaki açıklamalardaki önyarg1 derecesinin şirketin çevresel performansına dayanarak sistematik olarak değiştiğini tespit etmişlerdir.. Çalışmada, daha kötü çevresel performansa sahip şirketlerin açıklamalarının daha iyi performans gösteren emsallerinden daha fazla "iyimserlik" ve daha az "kesinlik" sergilediğini varsayılmıştır.

Sun ve Diğ., (2010), çalışmalarında kurumsal çevresel açıklamalar ile kazanç yönetimi arasındaki ilişkiyi ve kurumsal yönetim uygulamalarının bu ilişki üzerindeki etkisini araştırmışlardır. Çalışmada Nisan 2006 ile Mart 2007 dönemi için 245 reel sektör İngiliz şirketinin kurumsal yönetim ölçütü olarak performansa uyumlu ihtiyari tahakkukları kullanılmıştır. Araştırma sonucunda, çevresel açıklama ile ihtiyari tahakkuk ölçütleri arasında belirli bir istatistiksel ilişkiye rastlanmamıştır. Ayrıca, kurumsal yönetim ilkelerinin çevresel açıklama ile kazanç yönetimi ilişkisi üzerindeki etkisinin çok az olduğu belirlenmiştir.

Da Silva Monteiro ve Aibar-Guzmán (2010) tarafindan Portekiz de faaliyet gösteren 109 firmanın 2002-2004 dönemi yıllık raporlarındaki çevresel açıklamaların içerik analizi yöntemiyle incelendiği çalışmada, ilgili dönemde yapılan çevresel bilgilendirme seviyesinin düşük olduğu tespit edilmiştir. Yine sonuçlara göre çevresel açıklama miktarı ile firma büyüklüğü ve şirketin borsaya kayıtlı olma durumu arasında olumlu yönde bir ilişki vardır.

Kavut (2010), çalışmasında, kurumsal sosyal ve çevresel açıklamalar ile kurumsal yönetim arasındaki ilişkiyi araştırmışlar, bu amaçla İMKB 100 endeksindeki şirketlerin tamamının 2003-2004 dönemi kurumsal yönetim uyum ve faaliyet raporlarını içerik analizi yöntemi ile incelemiştir. Çalışma sonucunda, şirketlerin çevresel bilgi düzeyinin incelenen dönemde artış göstermesine karşılık bu düzeyin uluslararası çevresel raporlama uygulamalarına nazaran yetersiz kaldığı tespit edilmiştir.

Iwata ve Okada (2011), 2004-2008 dönemi için 268 Japon imalat firmalarının verilerini kullanarak çevresel performansın finansal performans üzerindeki etkisini 
inceledikleri çalışmada, özellikle atık ve sera gazı emisyonu bilgilerini kurumsal çevre yönetimi faktörleri olarak analize dahil etmişlerdir. Araştırma sonuçlarına göre, atık emisyonunun mali performans üzerinde önemli bir etkisi yokken, sera gazı emisyonunun azalması temiz sektörlerde finansal performansı artırmaktadır. Ayrıca firma büyüme oranı arttıkça, firma performansı üzerindeki atık emisyonunun etkisi azalırken, sera gazı emisyonunun etkisi artmaktadır.

Zhongfu, Jianhui, ve Pinglin (2011) tarafından Çin de Şanghay Borsasına kayıtlı 445 imalat şirketinin 2008-2009 dönemi yıllık raporlarının incelendiği çalışmada, firmaların ekonomik performansları ile çevresel bilgiye dayalı açıklamaları arasındaki ilişki araştırılmıştır. Araştırma sonucunda çevresel bilgilendirmenin ekonomik performans üzerinde olumlu etkisi olduğu sonucuna ulaşılmıştır.

Acereta,Liena ve Moneva (2011), çalışmalarında, İspanya'daki ücretli otoyol işletme hakkına sahip şirketler tarafından yapılan çevresel bilgilendirmede, muhasebe raporlama standartlarının ne ölçüde benimsendiğini araştırmışlardır. İçerik analizi yöntemi kullanılarak 1999-2007 dönemi şirket finansal tablolarında çevresel açıklamalara ne derece yer verildiği tespit edilmeye çalışılmıştır. Araştırma sonucunda ele alınan dönemde çevresel açıklama miktarında yıllar itibariyle giderek artış görüldügüu, ancak yine de yapılan çevresel açıklama miktar ve kalitesinin düşük düzeyde olduğu tespit edilmiştir.

Galani, Gravas ve Stavropoulos (2011), 2009 yılı 34 Yunan şirketinin yıllık raporlarındaki çevresel açıklamalar ile firma özellikleri(büyüklük, karlılık)arasındaki ilişkiyi inceledikleri çalışmada, çoklu lineer regresyon analizi yapmışlar ve büyüklük ile çevresel bilgi açıklamaları arasında pozitif yönlü ilişki tespit etmişlerdir. Karlılık açısından şirketlerin çevresel açıklama uygulamaları arasında anlamlı bir fark bulunamamıştır.

Suttipun ve Stanton (2012), Tayland Menkul Kiymetler Borsasına kayıtlı 75 şirketin 2007 y1lı yıllık raporlarında sunulan çevresel bilgilendirme içeriğini incelemişlerdir. Yıllık faaliyet raporlarındaki en fazla bilgilendirmeyi kaynak sektörü şirketleri yaparken en düşük bilgilendirme yapan şirketler tarım ve gıda sektörüne aittir. Y1llık raporlardaki en yaygın çevresel raporlama kurumsal yönetim başlığı altında verilmiş, en yaygın açıklama konuları ise, çevre politikaları, çevre faaliyetleri ve atık yönetimi olarak tespit edilmiştir. Araştırma sonuçlarına göre, çevresel açıklama miktarı ile şirketin büyüklüğü arasında olumlu yönde bir ilişki vardır.

Khaveh ve Diğ., (2012) çevresel ve sosyal performansa dair açıklamaları inceledikleri çalışmada, Malezya'daki halka açık 45 şirketin 2008-2010 dönemi sürdürülebilirlik raporlarını inceleyerek belirledikleri çevresel göstergeler çerçevesinde raporları puanlandırmışlar ve söz konusu raporlarla net kar ve hisse senedi fiyatları arasındaki ilişkiyi regresyon analizi ile araştırmışlardır. Araştırma sonucunda, sürdürülebilirlik açıklamaları ile net kar ve hisse fiyatı arasında olumlu bir ilişki olduğu sonucuna ulaşılmıştır.

De Villiers ve Van Staden (2012), tarafindan Yeni Zelandalı hissedarlar ile yapılan anket çalışmasında, hissedarların çevresel bilgilendirme konusunda olumlu düşünceye sahip oldukları, işletmenin çevresel etkilere karşı hesap verebilir olmasını istedikleri, çevresel bilgilendirmenin zorunlu hale getirilmesi, denetlenmesi ve şirket web sayfasında yayınlanması konusunda istekli oldukları tespit edilmiştir. 
Iatridis (2013), çalışmasında farklı çevre bilgilendirme skorlarına sahip şirketlerin finansal özelliklerini çevresel açıklama ile çevresel performans çerçevesinde incelemiş, aynı zamanda çevresel açıklamaların kalitesini, kurumsal yönetim ve çevresel performans açısından ele alarak, söz konusu açıklamaların yatırımcı algısı üzerindeki etkisini de araştırmıştır. Çalışmanın sonucunda, çevresel açıklamanın çevresel performansla bağlantılı olduğu, büyük ölçek, sermaye ihtiyac1, karlılık ve sermaye harcamaları gibi şirket özellikleri ile çevresel açıklama kalitesi arasında olumlu bir ilişki olduğu tespit edilmiştir. Yine analiz sonuçlarına göre çevresel bilgi kalitesi yüksek olan şirketler etkin bir kurumsal yönetim uygulamasına sahiptir ve daha kolay şekilde sermaye piyasalarına erişim sağlamaktadırlar.

Bowrin (2013), Karayipler'de halka açık 55 şirket üzerinde yaptığ çalışmada, şirketlerin sosyal ve çevresel açıklama seviyeleri ve bu seviyeyi etkileyen faktörleri araştırmıştır. Araştırmada çoklu regresyon analizi uygulanmıştır. Çalışma sonuçlarına göre, açıklama miktarı ile firma büyüklüğü, kurum kültürü, yabancı etkisi ve endüstriyel bağlantı arasında olumlu yönde ilişki olmasına karşılık karlılık, milli kültür, kamu finansmanının önemi, cinsiyet çeşitliliği ve yönetim kurulu bağımsızlığı ile açıklama miktarı arasında anlamlı bir ilişkiye rastlanmamıştır.

Makori ve Jagongo (2013), tarafından çevre muhasebesi ile firma karlılığ1 arasındaki ilişkinin araştırıldığı çalışmada, Hindistan'da Bombay Borsasına kayıtlı 14 şirkettin 2007 yılı raporları ve kullanılan hesaplar çoklu regresyon modeli kullanılarak analiz edilmiştir. Çevre muhasebesi uygulama göstergesi olarak firmaların çevre korumaya yönelik yaptıkları harcama tutarı esas alınmıştır. Sonuçlar çevre muhasebesi uygulaması ile hisse başına kar ve işletme sermaye getirisi arasında negatif yönlü ilişkili olduğunu gösterirken, net kar marjı ve hisse başına temettü ile pozitif ilişkili olduğunu göstermiştir.

Andrikopulos ve Kriklani (2013), yaptıkları çalışmada Kopenhag Borsasına kayıtlı şirketin web sitelerindeki açıklamaları incelemişler ve çalışma sonucunda firma büyüklüğü, kaldıraç oranı, piyasa değeri/defter değeri ve karlılık ile çevresel açıklama miktarı arasında önemli bir etkileşim olduğu sonucuna ulaşmışlardır.

Burgwal ve Vieira (2014), çalışmalarında Hollanda borsasında kayıtlı 28 şirketin 2008 yılı çevresel açıklamalarını içerik analizi ile incelemişlerdir. Çalışma sonucunda firma büyüklügü ve içinde bulunulan sektör ile çevresel açıklama düzeyi arasında olumlu ilişki tespit edilirken, karlılık ile çevresel açıklama miktarı arasında anlamlı bir ilişki bulunamamıştır.

Akbaş (2014), çalışmasında Borsa İstanbul 100 endeksinde yer alan 62 reel sektör firmasının, çevresel açıklama miktarı ile firma özellikleri arasındaki ilişkiyi incelemiş, bu amaçla örneklemi oluşturan firmaların 2011 yılı faaliyet raporları içerik analizi yöntemi ile değerlendirilmiştir. Regresyon analizi yapılan çalışmanın sonuçlarına göre, firma büyüklüğü ve içinde bulunulan sektör; çevresel açıklamaların miktarı ile pozitif yönlü ilişkili iken, karlılık negatif yönlü ilişkilidir. Firma yaşı ve kaldıraç oranı ile çevresel açıklamaların miktarı arasında ise istatistiksel açıdan anlamlı bir ilişki bulunmadığı tespit edilmiştir.

Chang (2015), Çin deki sekiz ağır kirlilik endüstrisinde faaliyet gösteren 124 firmanın 2008-2012 verilerini kullanarak gerçekleştirdiği çalışmada, çevresel performans ve çevresel açıklamanın finansal performans üzerindeki etkisini 
araştırmıştır. Birim kök ve panel veri eş bütünleşme testi uygulanan araştırma sonuçlarına göre, çevresel performansın firmanın Tobin $Q$ değeri üzerinde önemli ölçüde olumsuz etkisi varken, çevresel eğilim ile firma değeri arasında olumlu etkileşim tespit edilmiştir.

Eljayash (2015), çalışmasında Mısır, Libya ve Tunus ülkelerinde faaliyet gösteren 12 petrol şirketinin 2008-2010 dönemi yıllık raporlarında çevresel açıklamaların miktar ve kalitesini ölçmek amacıyla içerik analizi yöntemini kullanmış ve çevre uygulama indeksi oluşturmuştur. Araştırma sonucu, incelenen şirketlerin ilgili dönemde çevresel açıklama düzeyinde hafif bir artış olmasına rağmen hala düşük seviyede olduğunu göstermiştir.

Çetin, Varan ve Fışkın (2015), Türkiye'de faaliyet gösteren 41 firmanın 20122013 dönemi kurumsal sosyal sorumluluk ve sürdürülebilirlik raporlarını paydaş yönetimi ve katılımı açısından inceledikleri çalışmada içerik analizi yöntemini kullanmışlardır. Çalışma sonucunda, incelenen raporlardaki paydaşlar ile ilgili açıklamalarda paydaş yönetimi kavramının ön planda tutulduğu, ancak paydaş katılımı ile ilgili açıklamaların yetersiz kaldığ tespit edilmiştir. Yine "çevre" sözcüğünün sağlık ve finans sektörü firmalarında daha sık kullanıldığı tespit edilmiştir.

Can ve Güney (2015), çalışmalarında BİST 100 Endeksindeki 39 imalat şirketinin 2013 yılı faaliyet raporlarında yer alan çevresel açıklamaların niteliksel durumunu içerik analizi yöntemiyle incelemişlerdir. Çalışma sonucunda faaliyet raporlarındaki çevresel bilgilerin niteliksel olarak yetersiz olduğu, bu durumun da büyük oranda çevresel verilerin açıklanmasında standart bir raporlama şeklinin ve yasal zorunluluğun olamamasından kaynaklandığı tespit edilmiştir.

Önce, Onay ve Yeşilçelebi (2015), Türkiye'de kurumsal sürdürülebilirlik raporlamasının mevcut durumunu araştırdıkları çalışmada, 2005-2014 yılları arasında 72 işletme tarafından yayınlanan 181 sürdürülebilirlik raporunu GRI'nın baz aldığı 26 ölçüte göre incelemişlerdir. Çalışma sonucunda y1llar itibariyle yayınlanan sürdürülebilirlik raporu sayısının arttığı, rapor türü olarak GRI'nın tercih edildiği ve en çok imalat sektöründeki kuruluşların rapor yayınladığı görülmüştür. Çalışmaya göre Türkiye de sürdürülebilirlik anlayışını dikkate alan firma sayısı giderek artmaktadır.

Almagtome (2015), ulusal kültürel değerlerle ilgili kurumsal çevresel açıklama düzeyleri arasındaki ilişkiyi araştırmıştır. 20 ülkeden 6 sanayi sektöründe faaliyet gösteren 655 şirketin 2012 yılına ait yıllık raporlarının içerik analizi ile değerlendirildiği çalışma sonuçlarına göre kültürel değerlerle çevresel açıklama düzeyi arasında bir etkileşim vardır ve firma ölçeği, bölge ve sektör farklılaştıkça çevresel açıklama miktarı da değişmektedir.

Li ve Diğ., (2016), yaptıkları çalışmada Çin'de metal endüstrisinde faaliyet gösteren 205 şirketin 2008-2012 dönemi raporlarını incelemişler ve çalışma sonucunda, şirket büyüklügü, karlılık ve hükümet düzenlemeleri değişkenleri ile çevresel açıklama düzeyi arasında pozitif ilişki tespit etmişlerdir.

\section{VERI VE METODOLOJI}

\subsection{Veri Seti}

$\mathrm{Bu}$ araştırmada Borsa İstanbul'da işlem gören ve kimya, petrol, kauçuk ve plastik ürünler sektöründe faaliyet gösteren firmalara ait yıllık faaliyet raporları, bilanço ve 
gelir tablosundaki bazı bilgiler veri seti olarak kullanılmıştır. Araştırmaya konu olan firmalardan sadece 19 tanesi için; 2008-2014 yılları arasında kesintisiz veriye ulaşılabilmiştir. Bu nedenle araştırmaya konu olan örneklem 2008-2014 yılları için 19 adet firma ile sınırlandırılmıştır. Buna göre araştırmaya dahil edilen firmalar Tablo 1'de olduğu gibidir.

Tablo 1. Araștırmaya Dahil Edilen Firmalar

\begin{tabular}{|c|c|}
\hline $\begin{array}{l}\text { Firma } \\
\text { Kodu }\end{array}$ & Firmanın Adı \\
\hline AKSA & AKSA AKRİLIKK KİMYA SANAYİI A.Ş. \\
\hline ALKIM & ALKİM ALKALİ KİMYA A.Ş. \\
\hline AYGAZ & AYGAZ A.Ş. \\
\hline BAGFS & BAGFAŞ BANDIRMA GÜBRE FABRIKKALARI A.Ş. \\
\hline BRISA & BRISAA BRIDGESTONE SABANCI LASTIKK SAN. VE TİC. A.Ș. \\
\hline DEVA & DEVA HOLDING A.Ş. \\
\hline DYOBY & DYO BOYA FABRİKALARI SANAYİ VE TİCARET A.Ş. \\
\hline EGGUB & EGE GÜBRE SANAYİİ A.Ş. \\
\hline EGPRO & EGE PROFİL TİCARET VE SANAYİ A.Ş. \\
\hline GOODY & GOODYEAR LASTİKLERİ T.A.Ş. \\
\hline GUBRF & GÜBRE FABRİKALARI T.A.Ş. \\
\hline HEKTS & HEKTAŞ TİCARET T.A.Ş. \\
\hline MRSHL & MARSHALL BOYA VE VERNIK SANAYIII A.Ş. \\
\hline PETKM & PETKIMM PETROKİMYA HOLDINGG A.Ş. \\
\hline PIMAS & PİMAŞ PLASTİK İNŞAAT MALZEMELERİ A.Ş. \\
\hline SASA & SASA POLYESTER SANAYİ A.Ş. \\
\hline SODA & SODA SANAYİİ A.Ş. \\
\hline TRCAS & TURCAS PETROL A.Ş. \\
\hline TUPRS & TÜPRAŞ-TÜRKİYE PETROL RAFİNERİLERİ A.Ş. \\
\hline
\end{tabular}

Araştırmada bu 19 firmanın yıllık faaliyet raporları ve mali tablolarından faydalanarak çevresel açıklamalar, firma büyüklüğü, özsermaye karlılığı, varlık karlılığı, kaldıraç oranı, borsaya kote olma tarihi ve kuruluş tarihi esas alınarak ilgili değişkenler hesaplanmıştır.

Araştırmada çevresel açıklama düzeyi, ÇAM olarak ifade edilmiştir. Bu değişken hesaplanırken her bir firmanın 2008-2012 dönemindeki 5 yıl için ayrı ayrı faaliyet raporlarında içerik analizi yapılmıştır. Buna göre çevre, ekolojik, doğa, hava, su, toprak, görüntü, rüzgar, güneş, yenilebilir, doğal gaz, petrol, kömür, tazminat, temizlik, sera gazı, arıtma, dönüşüm, enerji, emisyon, kimyasal, kirlilik, atık, sorumluluk, biyoçeşitlilik, azaltma, ISO-50001, ISO- 14001, TS1-6001, ISO-14064, yeşil, orman, fidan, tasarruf, tüketim, ozon, iklim, çed, karbon, gürültü, zararsı, ekosistem, sürdürülebilir, 1slah, duyarlı, rekreasyon, toksik, koku, tehlikeli, koruma, kurtarma, döküntü kelimelerinin sayısı her yıl için, ilgili firmanın çevresel açıklama düzeyi değişkeni olan ÇEM'i oluşturmuştur. Büyüklük değişkeni ise firmanın ilgili yıldaki toplam varlıklarının logaritmasının alınması ile elde edilen değer olup, BÜYÜKLÜK olarak ifade edilmektedir. Kaldıraç oranı, her firmanın toplam borç düzeyinin, toplam varlıklarına bölünmesi ile elde edilen değişken olup, BORÇLANMA olarak ifade edilmiştir. Kuruluş yaşı ise firmanın kurulduğu tarihin esas alınması ile ilgili yıldaki yaşını ifade etmekte olup, KURULUŞYAŞI olarak kullanılmaktadır. Kote olma yaşı ise 
firmanın borsaya kote olduğu tarihin esas alınması ile ilgili yıl için hesaplanan yaşı göstermekte olup, KOTEYAŞ olarak ifade edilmektedir. Özsermaye verimliliği, net karın özsermayeye oranı olup, ROE şeklinde ifade edilmektedir. Varlık karlılığı ise net karın toplam varlıklara oranı olup, ROA şeklinde ifade edilmektedir.

Araştırmaya dahil edilen değişkenlerden büyüklük, kuruluş yaşı, kote yaşına ait olan değerlerin logaritması alınmış olup, diğerlerine böyle bir dönüşüm uygulanmıştır. $\mathrm{Bu}$ nedenle regresyon modeline ait sonuçlar bu doğrultuda yorumlanmıştır.

Firmaların çevresel açıklama düzeyinin, ilgili firmaya ait olan hangi karakteristik özellikten etkilendiğini incelemek amaciyla gerçekleştirilen bu çalışmada Borsa İstanbul'a kote olan ve 7kimya sektöründe faaliyet gösteren toplam 19 firma için 7'şer dönemde bu araştırma gerçekleştirilmiştir. İlgili literatürde genel olarak yatay kesit verisi (tek bir yıl) için gerçekleştirilen çalışmalar çevresel açıklamaların firma karakteristik özelliklerinden nasıl etkilendiğini sınırlı bir dönem için göstermekte olup, ulaşılan bilgilerin genele yorumlanması kısıtlıdır. Oysaki bu çalışmada panel veri seti kullanılarak, Borsa İstanbul kimya sektöründe faaliyet gösteren firmalar için daha güvenilir ve genellenebilir sonuçlar vermesi nedeniyle ayrıca önemlidir. Buna göre her bir değişken için 133 adet veri seti hesaplanmış olup, toplamda 931 adet veri ile tüm analizle gerçekleştirilmiştir.

\subsection{Metodoloji}

$\mathrm{Bu}$ çalışmada da kimya sektöründe faaliyet gösteren firmaların 2008-2014 dönemindeki çevre açıklama düzeyleri ile firmanın büyüklük, borçlanma düzeyi, kuruluş yaşı, borsaya kote olma yaşı, özsermaye karlılığ özellikleri arasındaki ilişki panel regresyon analizi ile incelenmektedir. Panel veri analizleri ile bir den fazla firmaya ait olan çevresel açıklama düzeyi, birden fazla yıl için firma özellikleri ile ilişkilendirilebilmektedir. Buna göre araştırmada kullanılan model aşağıdaki gibi oluşturulmuştur.

$$
\begin{aligned}
\text { ÇAM }_{i}= & \alpha+\beta_{1} \text { BÜYÜKLÜK } \\
& \beta_{4} \text { KOTEYAŞI }_{i t}+\beta_{5} \operatorname{ROA}_{2} \text { BORÇLANMA }_{i t}+\beta_{6} \text { ROE }_{i t}+\varepsilon_{i t}
\end{aligned}
$$

Araştırmada kullanılan veri seti dengeli panel olduğundan kullanılan modelde bu veri setine uygun olarak belirlenmiştir. Panel regresyon modeli incelenmeden önce panel birim kök analizleri ise Levini Lin, Chu (LLC) ile yapılmıştır. Bu test ile ortak birim kök araştırmaları gerçekleştirilmektedir. LLC(2002) panel birim kök testine ait hipotezler:

$\mathrm{H}_{0}$ : Tüm panel durağan değildir.

$\mathrm{H}_{1}$ : Tüm panel durağandır, şeklindedir.

Araştırmada incelenen tüm değişkenlere ait birim kök incelemesi gerçekleştirildikten sonrra panel regresyon modeli tahmini için Hausmann (1978) testi uygulanmıştır. Hausmann (1978) testi ile panel regresyon analizi için tesadüfi etkiler mi yoksa sabit etkiler mi modelinin seçileceğine karar verilmektedir. Hausmann (1978) testinde hipotezler ise aşağıdaki gibidir.

$\mathrm{H}_{0}$ : Tesadüfi etkiler modeli sabit etkiler modelinden daha etkindir. 
$\mathrm{H}_{1}$ : Sabit etkiler modeli tesadüfi etkiler modelinden daha etkindir.

Hausmann testinde $\mathrm{H}_{0}$ hipotezine göre hata terimleri ile açıklayıcı değişkenler arasında ilişki bulunmamaktadır. Buna göre $\mathrm{H}_{0}$ hipotezinin kabul edilmesi; regresyon modelinin tesadüfi etkiler modeline göre, red edilmesi ise sabit etkiler modeline göre tahmin etmeyi gerektirmektedir.

\section{Araştırmaya İlişkin Bulgular}

Araştırma kapsamında incelenen firmalara ait tanımlayıcı istatistik değerleri Tablo 2 'de olduğu gibidir.

Tablo 2. Değişkenler İçin Tanımlayıcı İstatistik Değerler

\section{Panel : Bağımlı ve Bağımsız Değişkenler}

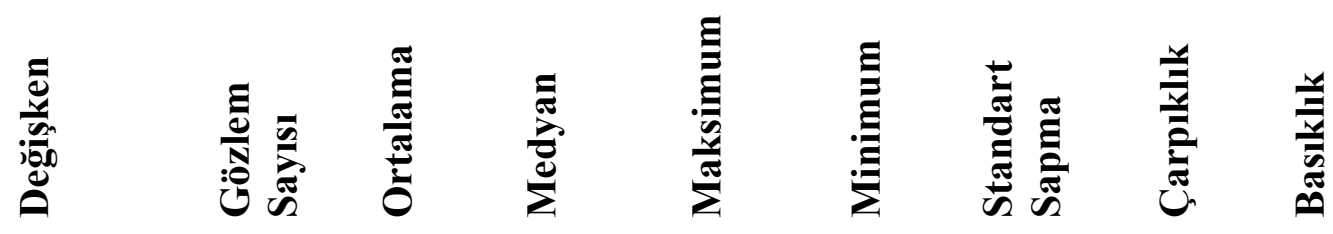

\begin{tabular}{lrrrrrrrr}
\hline \hline ÇEM & 133 & 79,038 & 17,000 & 1012,000 & 1,000 & 159,985 & 3,216 & 14,581 \\
BORÇLANMA & 133 & 0,456 & 0,432 & 0,913 & 0,024 & 0,178 & 0,184 & 2,946 \\
BÜYUUKLÜK & 133 & 19,104 & 19,547 & 22,055 & 12,876 & 2,291 & $-1,309$ & 3,869 \\
KOTEYAŞ & 133 & 21,099 & 22,993 & 27,990 & 7,998 & 5,446 & $-0,828$ & 2,638 \\
KURULUŞYAŞ & 133 & 41,248 & 430650 & 62,340 & 18,030 & 10,833 & $-0,355$ & 2,134 \\
ROA & 133 & 0,045 & 0,054 & 0,268 & $-0,187$ & 0,067 & $-0,439$ & 4,825 \\
ROE & 133 & 0,065 & 0,093 & 0,453 & $-1,199$ & 0,193 & $-3,821$ & 24,050 \\
\hline \hline
\end{tabular}

Elde edilen tanımlayıcı istatistik değerlere göre araştırmaya dahil edilen kimya sektöründe faaliyet gösteren 19 farklı firmanın, 2008-2014 dönemindeki 7 yıl için düzenlenen faaliyet raporlarına göre, ortalama olarak 79,038 çevresel açılklama beyanatında bulunmuştur. İncelenen dönemde en fazla 1012, en az ise 1 tane çevresel açıklama sözkonusudur. Firmaların ortalama borçlanma oranı 0,456 olup, varlık karlılığ 10,045 , özsermaye verimliliği ise 0,065 'tir. Firmaların ortalama varlık büyüklüğü 197.652.148 TL olup, bu değer maksimum 3,778,954,585 TL, minimum 390,298 TL olarak belirlenmiştir. İncelen firmaların ortalama kuruluş yaş1 41,248 olup, en eski firma 62,340 , en yeni firma ise 18,030 'dır. Firmaların borsada işlem görme zamanı esas alındığ 1 durumunda ise 21,099 , en eski firma 27,990 , en yeni firma ise 7,998 y1l borsada işlem görmektedir.

İncelenen değişkenlerin birbiri ile olan ilişsilerini gösteren korelasyon değerleri ise Tablo 3'de olduğu gibidir. 


\begin{tabular}{|c|c|c|c|c|c|c|c|}
\hline & $\begin{array}{l}\sum_{i=1} \\
\text { d }\end{array}$ & 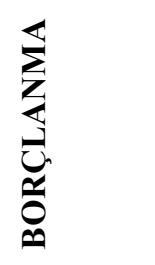 & صـ & $\begin{array}{l}\frac{n}{1} \\
0 \\
0 \\
0\end{array}$ & 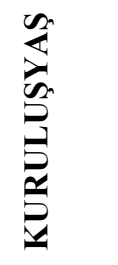 & $\underset{\mathbf{0}}{\overleftrightarrow{\simeq}}$ & $\stackrel{5}{0}$ \\
\hline ÇEM & 1 & & & & & & \\
\hline BORÇLANMA & $0,170 * *$ & 1 & & & & & \\
\hline BÜYÜKLÜK & $-0,243 *$ & $-0,029$ & 1 & & & & \\
\hline KOTEYAS & $-0,057$ & $0,353^{*}$ & 0,063 & 1 & & & \\
\hline KURULUŞYAŞ & $-0,357$ & $-0,141$ & $-0,175^{* *}$ & $0,191 * *$ & 1 & & \\
\hline ROA & 0,089 & $-0,428 *$ & 0,002 & $-0,069$ & 0,065 & 1 & \\
\hline ROE & $0,194 * *$ & $-0,286^{*}$ & $-0,029$ & $-0,009$ & 0,039 & $0,795^{*}$ & 1 \\
\hline
\end{tabular}

Değişkenler arasındaki korelasyon katsayılarına göre firmaların çevresel açıklamaları ile büyüklük arasında negatif yönlü bir ilişki söz konusudur. Bu ilişki \%1 anlamlılık düzeyinde istatistiksel olarak anlamlıdır. Ayrıca borçlanma düzeyi ve özsermaye verimliliği ile çevresel açıklamalar arasında pozitif yönlü bir ilişki söz konusu olup, bulunan sonuç $\% 5$ anlamlılık düzeyinde istatistiksel olarak anlamlıdır.

Değişkenler arasında uygun panel regresyon modeli seçimine geçmeden önce panel birim kök testlerinden Levin, Lin, Chu (LLC) $t$ istatistiği ile değişkenlerin birim kök analizi yapılmıştır. Buna göre LLC(2002) panel birim kök analizi sonuçları Tablo 4 'de olduğu gibidir.

Tablo 4. Birim Kök Analizi Sonuçları

\begin{tabular}{l||cc} 
DEĞIŞKENLER & Levin, Lin, Chu t İstatistiği & Olasılık \\
\hline \hline \multirow{2}{*}{$\begin{array}{l}\text { ÇEM } \\
\text { BORÇLANMA }\end{array}$} & $-4,076$ & $0,000^{*}$ \\
\cline { 2 - 3 } BÜYUULÜK & $-4,580$ & $0,000^{*}$ \\
\cline { 2 - 3 } KOTEYAŞI & $-60,978$ & $0,000^{*}$ \\
\cline { 2 - 3 } \multirow{2}{*}{$\begin{array}{l}\text { KURULUŞYAŞI } \\
\text { ROA }\end{array}$} & $-76,072$ & $0,000^{*}$ \\
\cline { 2 - 3 } ROE & $-2,134$ & $0,000^{*}$ \\
\cline { 2 - 3 } & $-9,467$ & $0,000^{*}$ \\
\hline \hline
\end{tabular}

*, \%1 düzeyinde anlamlıdır.

Değişkenlere ait olarak uygulanan LLC(2002) panel birim kök testine ait olasılık değerleri \%10'dan daha küçüktür. Dolayısıyla temel hipotez red edilip, alternatif hipotez kabul edilir. Buna göre araştırmada kullanılan tüm panel durağandır, denilebilir.

Araştırmada kullanılacak değişkenlerin durağan olduğu belirlendikten sonra panel veri analizinin çözümleneceği modele karar verilmelidir. Uygulanacak panel regresyon modelinin tesadüfi etkiler mi, yoksa sabit etkiler mi modeline göre tahmin edilmesi gerektiğini belirlendiği Hausmann (1978) testi sonuçları Tablo 5'de olduğu gibidir. 
Tablo 5. Hausmann Test İstatistiği Sonuçları

Sabit Etki Tesadüfi Etki

Var.(Fark) Olasılık

\begin{tabular}{lllll}
\hline $\begin{array}{l}\text { ÇEM } \\
\text { (BağımlıDeğişken) }\end{array}$ & & & & \\
\hline \hline BORÇLANMA & 227,306 & 314,677 & 3518,845 & 0,1408 \\
BÜYUUKLÜK & $-18,769$ & $-17,369$ & 9,067 & 0,642 \\
KOTEYAŞ & $-18,341$ & 6,875 & 103,937 & $0,013^{* *}$ \\
KURULUŞYAŞ & 1136,073 & $-48,330$ & 155201,650 & $0,002^{*}$ \\
ROA & 18,850 & 65,536 & 1442,718 & 0,219 \\
ROE & 3,867 & 42,441 & 116,379 & $0,000^{*}$ \\
\hline \hline $\mathbf{X}^{\mathbf{2}}$ & $\mathbf{2 2 , 9 5 3}$ & & \\
\hline \hline Olasılık & $\mathbf{0 , 0 0 0}, * *$ \%1 ve \%5 düzeyinde anlamlıdır.
\end{tabular}

Hausmann testi ile tesadüfi etkiler modelinin parametreleri ile sabit etkiler modelinin parametreleri arasındaki farkın istatistiksel olarak anlamlı olup olmadığ incelenmektedir. Elde edilen ki-kare test istatistiğine göre sonuç anlamlıdır. Panel regresyon analizi için $\mathrm{H}_{0}$ hipotezi red edilir. Buna göre sabit etkiler modeline göre panel regresyon modeli tahmin edilmelidir. Sabit etkiler modeline göre panel regresyon analizi sonuçları Tablo 6'da olduğu gibidir.

Tablo 6. Sabit Etkili Model İçin Panel Regresyon Analizi Sonuçları

\begin{tabular}{|c|c|c|c|c|}
\hline & Katsayı & Std. Hata & t İstatistiği & Olasılık \\
\hline SABİT & $-3458,267$ & 1251,575 & $-2,763$ & $0,006^{*}$ \\
\hline BORÇLANMA & 227,306 & 107,794 & 2,108 & $0,037 * *$ \\
\hline BÜYÜKLÜK & $-18,769$ & 6,659 & $-2,818$ & $0,005^{*}$ \\
\hline KOTEYAŞ & $-18,341$ & 10,847 & $-1,690$ & $0,093 * * *$ \\
\hline KURULUŞYAŞ & 1136,074 & 405,085 & 2,804 & $0,006^{*}$ \\
\hline ROA & 18,850 & 208,627 & 0,090 & 0,9282 \\
\hline ROE & 3,867 & 65,426 & 0,059 & 0,953 \\
\hline \multicolumn{3}{|c|}{ Toplam Panel Gözlemleri } & 133 & \\
\hline \multicolumn{3}{|c|}{ Dönem (2008-2014) } & 7 & \\
\hline \multicolumn{3}{|c|}{ KESİT(Firma sayısı) } & 19 & \\
\hline \multicolumn{3}{|l|}{$\mathbf{R}^{2}$} & 0,823 & \\
\hline \multicolumn{3}{|l|}{ Adj. $R^{2}$} & 0,784 & \\
\hline \multicolumn{3}{|c|}{ Durbin-Watson İstatistiği } & 2,211 & \\
\hline \multicolumn{3}{|l|}{ F Değeri } & 21,024 & \\
\hline \multicolumn{3}{|l|}{ Olasılık(F Değeri) } & 0,000 & \\
\hline
\end{tabular}

$*, * *, * * * \% 1, \% 5$ ve $\% 10$ düzeyinde anlamlıdır.

Elde edilen sabit etkili panel regresyon analizi sonuçlarına göre firmaların çevresel açıklama düzeylerini etkileyebileceği düşünülen altı adet firmaya özgü değişkenden; özsermaye karlılığı ve varlık karlılığı değişkenleri $\% 10$ anlamlılık düzeyinde istatistiksel olarak anlamlı değildir. Ancak bu iki değişkende çevresel açıklama düzeyini pozitif olarak etkilemektedir. Bu değişkenlerin dışındaki seçilen tüm diğer firma karakteristik özellikleri ise \%10 anlamlılık düzeyinde istatistiksel olarak anlamalıdır. Elde edilen sonuçlara göre Borsa İstanbul'da kimya sektöründe faaliyet gösteren firmaların çevresel açıklama düzeyleri, ilgili firmanın borçlanma düzeyi ve 
kuruluş tarihinden pozitif yönde etkilenmektedir. Bu ilişki istatistiksel olarak da anlamlıdır. Ancak buna karşılık \%10 anlamlılık düzeyinde firmanın büyüklügü̈ ve borsaya kote olduğu tarih, firmaların çevresel açıklama düzeyini negatif olarak etkilenmektedir.

Regresyon modeline ait F Değeri \%10 anlamlılık düzeyinde dikkate alındığında modelin bütün olarak da anlamlı olduğunu ifade etmektedir. Firmaların özellikleri ile çevresel açıklama düzeyi arasındaki ilişkiyi açıklamak amacıyla oluşturulan modelin düzeltilmiş $\mathrm{R}^{2}$ değeri \%78 olup, modelin açıklama gücünün yüksek olduğu söylenebilir.

\section{SONUÇ}

Bu araştırmada kimya sektöründe faaliyet gösteren 19 firmanın 2008-2014 dönemindeki çevresel açıklama düzeyleri, firmanın büyüklüğü, özsermaye karlılı̆̆ı, aktif karlılığı, borçlanma düzeyi, borsaya kote olma tarihi, firmanın kuruluş tarihi esas alınarak incelenmiştir. Sabit etkiler panel regresyon analizinin uygulandığ araştırmada veriler Eviews 9 programında analiz edilmiştir.

Analiz sonuçlarına göre, firma büyüklüğü ile çevresel açıklama düzeyi arsında negatif bir ilişki olduğu tespit edilmiştir. Bu sonuç, Wu, Liu ve Sulkowski (2010) tarafından yapılan çalışma bulgularıyla paralellik arz ederken; literatürdeki firma büyüklüğü ile çevresel açıklama düzeyi arasında pozitif ilişki olduğunu gösteren bazı çalışma sonuçlarıyla tutarlı değildir (Akbaş, 2014; Almagtome, 2015; Al-Tuwaijri, Christensen ve Hughes, 2004; Bowrin, 2013; Da silva ve Guzman, 2010; Galani, Gravas ve Stavropoulos, 2011; Iatridis, 2013; Liu ve Anbumozhi, 2009; Patten, 2002; Pahuja, 2009; Suttipun ve Stanton, 2012). Wu, Liu ve Sulkowski (2010) yaptıkları çalışmada, firmaların büyüdükçe ve daha iyi bir finansal performans gösterdikçe, genellikle daha iyi çevre uygulamaları ve daha az çevresel sorunlara sahip olma olasılığı sebebiyle, çevresel konularda daha düşük raporlama yapma eğiliminde olacaklarını ifade etmişlerdir (Wu, Liu ve Sulkowski, 2010, s. 76). Büyüklük ile çevresel açıklama düzeyi arasında pozitif ilişki bulan çalışmalarda ise firma büyüklüğü arttıkça, çevreyi korumaya yönelik faaliyetlere ve teknolojilere ayırılabilecek kaynak miktarının küçük şirketlere nazaran daha fazla olacağı ve yine görünürlük ve kamu baskısı nedeniyle büyük şirketlerin gönüllü çevresel açıklama yapma olasılığının daha fazla olacağ vurgulanmaktadir (Almagtome, 2015, s. 167; Da silva ve Guzman, 2010, s. 188; Huang ve Kung, 2010, s.449; Pahuja, 2009, s. 232).

Ele alınan diğer bir şirket özelliği olan kaldıraç oranı ile çevre açıklama düzeyi arasında pozitif bir ilişski bulunmuştur. Bu durum literatürdeki bazı çalışmalarla uyumludur (Burgwal ve Vieira, 2014, s. 60 ; Clarkson ve Diğ., 2008, s. 314; Huang ve Kung, 2010, s. 445; Pahuja, 2009, s. 233). İlgili çalışmalarda kaldıraç oranı arttıkça yatırımcıların şirketin çevresel performansını da içeren genel faaliyet performansını izleme talebinin artacağı ve temsil maliyetlerini azaltmak için kurumsal açıklamaları artırma yoluna gidileceği ifade edilmiştir. Kredi kuruluşlarının bilgi ihtiyacının fazlalığı nedeniyle, gelişmiş ekonomilerde özellikle bankacılık sektörünün çevre raporu kavramının gelişmesinde oldukça aktif rol oynadığı bilinmektedir (Özbirecikli, 2002). Yine borçlanma oranı arttıkça yeni teknoloji elde etme ve bu paralelde çevreyi korumaya yönelik yatırımlarda bulunabilme imkanı artmaktadır. Diğer yandan kaldıraç oranı ile çevresel açıklama miktarı arasında negatif ilişki olduğunu tespit eden bir grup yazar ise düşük kaldıraç oranına sahip şirketlerin çevresel açıklamaları finanse etmek 
için yeterli fona sahip olmasının daha olası olduğunu ve kreditörlerden gelen daha az baskı nedeniyle şirketin finansal başarısını dolaylı etkileyen çevresel açıklamalar gibi örgütsel faaliyetlere odaklanmalarının daha kolay olacağını söylemişlerdir (Andrikopoulos ve Kriklani, 2013; Brammer ve Pavelin, 2006-2008'den aktaran: Akbaş, 2014, s. 148; Wu, Liu ve Sulkowski, 2010). Wu, Liu ve Sulkowski (2010) çalışmalarında, çevresel bilgi açıklamalarının yüksek kaldıraç oranına sahip firmalarda özel maliyetleri artıracağını ve artan maliyetler nedeniyle kredi görüşmelerinin daha zor ve maliyetli olacağını vurgulamışlardır. Yine yüksek kaldıraç oranına sahip firmalarda çevresel düzenlemelere ve yasalara uyma olasılığı daha yüksek olacağından raporlarda gösterilecek daha az çevresel sorun olacağı ifade edilmiştir ( $\mathrm{Wu}$, Liu ve Sulkowski, 2010, s. 79).

Yaş değişkeni ise bu çalışmada kuruluş yaşı ve kote yaşı olmak üzere iki açıdan ele alınmıştır. Analiz sonucunda şirketin kuruluş yaşı ile çevresel açıklama miktarı arasında olumlu yönde ilişki tespit edilmiştir. Bu sonuç literatürdeki bazı çalışma sonuçlarıyla tutarlıdır (Liu ve Anbumozhi, 2009). Şirketin kuruluş yaşının, şirketin kararlılığının, stratejik duruş, finansal performans ve paydaş gücünün bir göstergesi olarak kabul edilebileceği ifade edilmektedir (Liu ve Anbumozhi, 2009, s.597). Ayrıca şirket faaliyet süresi uzadıkça, şirketin bilgi birikimi, tecrübesi, edindiği çevre, kaynaklara ulaşabilme kolaylığı, yönetsel becerileri vb. özelliklerinin de artacağı; çevresel bilgi açıklamaları ve çevre koruma faaliyetlerinin şirketin itibarını, imajını, şirket değerini ve kalıcılığını yükselttiği söylenmiştir (Roberts, 1992, s.605' den aktaran: Akbaş, 2014, s. 150).

İşletmenin borsaya kote olduğu yaş ile çevresel açıklama düzeyi arasında ise negatif yönde ilişki tespit edilmiştir. Literatürde bu değişkene ilişkin bir çalışmaya rastlanmamıştır. Borsada işlem görmeye başladıktan sonra işletmenin ortaklık ve sermaye yapısının etkilendiği, hisseleri geniş bir yatırımcı portföyüne yayılmış olan işletmelerde dağınık ortaklık yapısı nedeniyle işletmeyi gözetim altında tutmada ortakları birleştirecek bir etken olmadığından genel olarak performans düşüklüğü yaşanabileceği söylenmektedir (Sorensen, 2006'dan akratan: Durak ve Taşkın, 2014, s. 33). Kanaatimizce bu durum genel performans bileşenlerinden olan çevresel performans içinde söylenebilir. Borsaya kote olmak işletmeler için önemli bir adımdır. Ancak işletmeler başarıya ulaştıklarında davranışsal bir katılık içine girebilmekte, değişikliklere daha az adapte olabildikleri için esnek kararlar verememekte, yenilikçi düşünceleri bile bünyelerinde kabul etmemektedirler (Loderer ve Waelchli, 2011'den aktaran: Durak ve Taşkın, 2014, s. 37). Başka bir açıdan bakılacak olursa elde edilen sonuç, şirket borsaya açıldıktan sonra, karar vericilerin çevre raporlama hakkında doğru karar veremedikleri, yatırımcıların ve hissedarların gözünü boyamak adına uzun vadede kar getirecek çevresel yatırımlardan kaçındıkları, kısa dönem karlılık rakamlarına odaklandıkları anlamında yorumlanabilir.

Son olarak analiz sonuçlarına göre özkaynak karlılığı ile varlık karlılığı değişkenleri ile çevresel açıklama miktarı arasında istatistiksel olarak anlamlı bir ilişki bulunamamıştır. Bu sonuç litaratürdeki bazı çalışma sonuçları ile uyumludur (Bowrin, 2013; Burgwal ve Vieira, 2014; Galani, Gravas ve Stavropoulos, 2011; Zheng ve Diğ., 2012). 
Gelecekte yapılacak çalışmalarda, farklı sektörlerden daha fazla firma analize dahil edilebilir. Böylece elde edilen sonuçlar, sektörel bazlı olarak gruplandırılabilir. Ayrıca bu çalışmada yapılan borsaya kote olma tarihi gibi literatürdeki çalışmalarda bulunmayan firma özellikleri de uygulanacak modele eklenebilir.

\section{KAYNAKÇA}

Acerete, B., Liena, F., Moneva, J., (2011). "Environmental disclosure in financial statements: an analysis of Spanish toll motorway concessionaires", Transportation Research Part D: Transport and Environment, Vol. 16, No. 5, 377-383.

Akbaş, H. E., (2014). "Company Characteristics and environmental disclosure:An empirical investigation on companies listed on Borsa Istanbul 100 indeks", Muhasebe ve Finansman Dergisi, Say1. 62, Nisan, 145-164.

Almagtome, A., (2015). Ulusal kültürel değerlerin kurumsal çevresel açıklamalara etkisi: karşılaştırmalı bir araştırma, Eskişehir Anadolu Üniversitesi Sosyal Bilimler Enstitüsü, (Yayımlanmamış Doktora tezi), Mayıs, Eskişehir.

Al-Tuwaijri, S., Christensen, T. E., Hughes, K. E., (2004). "The relations among environmental disclosure, environmental performance and economic performance: a simultaneous equations approach, Accounting, Organizations and Society, Vol. 29, No. (5-6), 447-471.

Andrikopoulos, A., Kriklani, N., (2013). "Environmental disclosure and financial characteristics of the firm:the case of Denmark", Corporate Social Responsibility and Environmental Management, Vol. 20, No. 1, 55-64.

Ateşoğlu, İ., Türker , A., (2010). "Konaklama işletmelerinin sosyal sorumluluk faaliyetlerine yaklaşımı: Muğla ili örneği”, Süleyman Demirel Üniversitesi İktisadi ve İdari Bilimler Fakültesi Dergisi, Cilt. 15, Say1:3, 207-226.

Berthelot, S., Cormier, D., Magnan, M., (2003). "Environmental disclosure research: review and synthesis", Journal of Accounting Literature, No. 22, 1-44.

Bewley, K., Li, Y., (2000). "Disclosure of environmental information by Canadian manufacturing companies: A voluntary disclosure perspective", Advances in Environmental Accounting and Management, Vol.1, 201-226.

Bowrin, A. R., (2013). "Corporate social and environmental reporting in the Caribbean”, Social Responsibility Journal, Vol.9, No.2, 259-280.

Burgwal, D. V. D., Vieira, R. J. O., (2014). "Environmental disclosure determinants in Dutch listed companies”, Revista Contabilidade\&Finanças, Vol. 25, No. 64, 6078.

Campbell, D., (2004). "A longitudinal and cross-sectional analysis of environmental disclosure in UK companies-a research note", The British Accounting Review, No. 36, 107-117. 
Can, A. V., Güney, C., (2015). "Faaliyet raporlarında yer alan çevresel bildirimler-BIST 100 endeksinde yer alan ve imalat sanayi sektöründe faaliyet gösteren şirketler üzerinde bir içerik analizi”, Akademik Sosyal Araştırmalar Dergisi, Yıl:3, Say1:15, 297-308.

Chang, K, (2015). "The impacts of environmental performance and propensity disclosure on financial performance: empirical evidence from unbalanced panel data of heavy-pollution industries in China”, Journal of Industrial Engineering and Management, Vol. 8, No. 1, 21-36.

Cho, C. H., Roberts, R. W., Patten, D. M., (2010). "The language of US corporate environmental disclosure", Accounting, Organizations and Society, Vol. 35, No. 4, 431-443.

Clarkson, P. M., Li, Y., Richardson, G. D., Vasvari, F. P., (2008). "Revisiting the relation between environmental performance and environmental disclosure: An empirical analysis", Accounting, Organizations and Society, Vol. 33, No. 4-5, 303-327.

Cowan, S., Gadenne, D., (2005). "Australian corporate environmental reporting: a comparative analysis of disclosure practices across voluntary and mandatory disclosure systems", Journal of Accounting \& Organizational Change, Vol. 1, No. 2, 165-179.

Çetin, Ç., Varan, S., Fışkın, C., (2015). "Sürdürülebilirlik raporlamasında paydaş katılımı: Türkiye'deki firmaların analizi”, Ege Stratejik Araştırmalar Dergisi, Cilt. 6, Say1. 1, 9-35.

Da Silva Monteiro, S. M., Aibar-Guzmán, B., (2010). "Determinants of environmental disclosure in the annual reports of large companies operating in Portugal", Corporate Social Responsibility and Environmental Management, Vol. 7, No. 4, 185- 204.

De Villiers, C., Van Staden, C., (2012). "New Zealand shareholder attitudes towards corporate environmental disclosure", Pacific Accounting Review, Vol. 24, No. 2, 186-210.

Durak, M. G., Taşkın, D. F., (2014). "Kurumsal yönetim uygulamalarının işletme performansı üzerindeki etkileri: BİST üretim şirketleri üzerinden bir uygulama", Mali Çözüm Dergisi, Sayı. 126, Kasım-Aralık, 29-56.

Eljayash, K. M., (2015). "Documentation of environmental disclosure practices in the oil companies in the countries of the arab spring - some evidences from Egypt, Libya and Tunisia", Journal of Economics, Business and Management, Vol. 3, No. 10, 954-960.

Galani, D., Gravas, E., Stavropoulos, A., (2011). "The relation between firm size and environmental disclosure", International Conference On Applied Economics ICOAE 2011, 179-186.

Gray, R., Javad, M., Power, D. M., Sinclair, C. D., (2001). "Social and environmental disclosure and corporate characteristics:a research note and extension", Journal of Business Finance-Accounting, Vol. 28, No. 3-4, 327-356. 
Harte, G., Owen, D., (1991). "Environmental disclosure in the annual the reports of British companies: a research note", Accounting, Auditing and Accountability Journal, Vol. 4, No. 3, 51-61.

Huang, C. L., Kung, F. H., (2010). "Drivers of environmental disclosure and stakeholder expectation: evidence from Taiwan", Journal of Business Ethics, Vol. 96, No. 3, 435-451.

Hughes, S. B., Anderson, A., Golden, S., (2001). "Corporate environmental disclosures: are they useful in determining environmental performance?", Journal of Accounting and Public Policy, Vol. 20, No. 3, 217-240.

Iatridis, G. E., (2013). "Environmental disclosure quality: evidence on performance, corporate governance and value relevance", Emerging Market Review, No. 14, $55-75$.

Iwata, H., Okada, K., (2011). "How does environmental performance affect financial performance? Evidence from Japanese manufacturing firms", Ecologial Economics, Vol. 70, No. 9, 1691-1700.

Kavut, F. L., (2010). "Kurumsal yönetim, kurumsal sosyal sorumluluk ve çevresel raporlama: İMKB 100 şirketlerinin çevresel açılamalarının incelenmesi”, İşletme İktisadı Enstitüsü Yönetim Dergisi, No. 66, 9-43.

Khaveh, A., Nikhashemi, S. R., Haque, A., Yousefi, A., (2012). "Environmental and social performance disclosure and shareholders' wealth - A perspective from Malezyan companies", Australian Journal of Business and Management Research, Vol. 1, No .12, 33-41.

Li, D., Linna, X., Yan S., Min, H., Shenggang R., (2016). “Assessing environmental information disclosures and the effects of Chinese nonferrous metal companies", Polish Journal of Environmental Studies, Vol. 25, No. 2, 663-671.

Liu, X., Anbumozhi, V., (2009). "Determinant factors of corporate environmental information disclosure: an empirical study of Chinese listed companies", Journal of Cleaner Production, Vol. 17, No. 6, 593-600.

Makori, D. M., Jagongo, A., (2013). "Environmental accounting and firm profitability: An empirical analysis of selected firms listed in bombay stock exchange, India", International Journal of Humanities and Social Science, Vol. 3, No. 18, 248-256.

Önce, S., Onay, A., Yeşilçelebi, G., (2015). “Kurumsal sürdürülebilirlik raporlaması ve Türkiye'deki durum”, Journal of Economics, Finance and Accounting, Vol. 2, No. 2, 230-252.

Özbirecikli, M., (2002). Çevre Muhasebesi: Kavramlar Uygulama Alanları, Araştırma Sonuçları, Naturel Kitap ve Yayıncılık, Ankara.

Pahuja, S., (2009). "Relationship between environmental disclosures and corporate characteristics:a study of large manufacturing companies in İndia", Social Responsibility Journal, Vol. 5, No. 2, 227-244.

Patten, D., (2002). "The relation between environmental performance and environmental disclosure: a research note", Accounting, Organizations, and Society, Vol. 27, No. 8, 763-773. 
Sun, N., Salama, A., Hussainey, K., Habbash, M., (2010). "Corporate environmental disclosure, corporate governance and earnings management", Managerial Auditing Journal, Vol. 25, No. 7, 679-700.

Suttipun, M., Stanton, P., (2012). "Determinants of environmental disclosure in Thai corporate annual report", International Journal of Accounting and Financial Reporting, Vol. 2, No. 1, 99-115.

Wu, J., Liu, L., Sulkowski, A., (2010). "Environmental disclosure, firm performance, and firm characteristics: An analysis of S\&P 100 firms", Journal of Academy of Business and Economics, Vol. 10, No. 4, 73-83.

Zeng, S. X., Xu, X. D., Dong, Z. Y., Tam, V. W., (2010). "Towards corporate environmental information disclosure: an empirical study in china", Journal of Cleaner Production, Vol. 18, No. 12, 1142-1148.

Zhongfu, Y., Jianhui, J., Pinglin, H., (2011). "The Study on the Correlation between environmental information disclosure and economic performance-with empirical data from the manufacturing industries at Shanghai Stock Exchange in Çhina", Energy Procedia, 5, 1218- 1224. 


\section{Relation Between Company Features And Environmental Statement Within Corporate Social Responsibility: An Application In Chemistry, Petroleum, Rubber And Plastics Products Industry}

\author{
Şule YILDIZ \\ Sakarya University \\ Faculty of Management \\ Department of Business, \\ Sakarya, Turkey \\ kasapoglu@,sakarya.edu.tr
}

\author{
Gülfen TUNA \\ Sakarya University \\ Faculty of Political Sciences \\ Department of Financial \\ Econometrics, Sakarya, Turkey \\ geksi@,sakarya.edu.tr
}

\author{
Vedat Ender TUNA \\ Sakarya University \\ Institute of Social Sciences \\ Sakarya, Turkey \\ vedattuna@hotmail.com
}

\section{Extensive Summary}

In the recent years, importance of environmental accounting and environmental reporting has increased due to the demand of information of the related parties on corporate environment activities and responsibilities. Nowadays, the challenging competition conditions in the business world makes the companies more sensitive against the environment for continuing their existence in parallel with sustainable growth and profitability targets. Because the community in which the businesses live request them to act more within social responsibility awareness, to give importance on activities bringing social benefits, to make less emission release by not polluting the environment and not using harmful technologies, to make better energy consumption and to make production by making better waste management.

In the presentation to be made with the stakeholders regarding completion of expectations in order to be sustainable, transparent and accountable companies, annual activity reports or environmental reports can be used as important tools. In these reports, information is given on environmental impacts of business activities such as companies' environmental policies, environmental management and environmental impact assessment systems, environmental costs and investments within corporate social responsibility.

This kind of voluntary environmental statements can be effective for increasing the companies' financial performance, market and brand value, corporate image and reputation in long term. For this reason, the companies give importance to this subject by themselves even without any legal obligations.

In this study, the reason of differentiation between companies regarding the environmental statement amounts which can be accepted as the indicator of environmental sensitivity and environmental performance of the companies for creating a better environment. It is thought that the results of study will be beneficial for investors and other stakeholder groups as well as it will be encouraging for business managers in making environment reporting by increasing the voluntary environmental statement amounts and for law makers in making it obligatory to include environmental information in financial tables. Again, due to the increasing importance of 
environmental statements, it is expected that it will contribute to the researches made in subjects such as environmental reporting and sustainability.

In this respect, the purpose of research is to review the relation between environmental statements levels and company features. To this end, activity reports of 19 companies making business in chemistry, petroleum, rubber and plastic products industry in Borsa Istanbul were inspected with content analysis method for 2008 - 2014. Environmental statement levels of companies are variables which are created as result of counting the words within the activity reports with content analysis method. As the features of company, size, equity profitability, asset profitability, leverage ratio, stock market listing date and foundation date variables are used. In this study, it was not found that the stock market listing date was used as a variable in the previous studies in the literature. At this point, this study is important for determination of impacts of the company's public offering date on the environment statements. In this research, annual activity reports and financial tables of 19 companies were used for calculating the related variables by taking environmental statements as base. The relation between variables were reviewed with panel regression analysis. Panel data analyses and environmental statement levels belonging to more than one companies can be related with the company features for more than one years. According to this, the model used in the research was created as follows.

$$
\begin{gathered}
\text { CAM }_{\mathrm{i}}=\alpha+\beta_{1} \text { SIZE }_{i t}+\beta_{2} \text { DEBTS }_{\text {it }}+\beta_{3} \text { AGEOFCOMP }_{\text {it }}+\beta_{4} \text { LISTINGAGE }_{i t}+ \\
\beta_{5} \text { ROA }_{i t}+\beta_{6} \text { ROE }_{i t}+\varepsilon_{i t}
\end{gathered}
$$

Panel unit root analyses were made with Levini Lin, Chu (LLC) before reviewing panel regression models. Hausmann (1978) test was applied for panel regression model estimation. With Hausmann (1978) test, it is decided whether to select random effects or fixed effects for the panel regression model. According to the results of Hausmann (1978), fixed effects panel regression model was decided.

According to the analysis results, negative and statistically meaningful relation was found between company size and environmental statement level. Positive and statistically meaningful relation was found between debt level and environmental statement level.

In this study, the age variable was quoted in two aspects as age of the organization and listing age. According to the analysis results, positive relation was found between company's age and environmental statement level while negative and statistically meaningful relation was found between stock market listing date and environmental statement level. No statistically meaningful relation was found between equity profitability and asset profitability variables and the environmental statement level.

In future studies, more companies from different sectors can be included in the analysis. Thus, the results obtained can be grouped with sectoral basis. In addition, features such as stock market listing date, which are not in the studies existing in literature, can be added to the model to be applied. 